\title{
Biological Explanations of Criminal Behaviour
}

\begin{abstract}
This chapter provides a historical and sociological overview of the biological explanations for violent and criminal behaviour. It starts with a detailed description of the seminal work by Cesare Lombroso (nineteenth century) and highlights the risks of biological determinism and the potential stigmatization raised by this line of research. It then discusses current trends of biologization and genetization of crime, by focusing on the specific studies in the fields of epigenetics and neurobiology.

The chapter aims to provide the reader with a critical reading of such trends through the lens of sociology. Specifically, it is outlined how previous and current biological and biosocial explanations of criminal behaviour can foster risks such as exclusion, marginalization and stigmatization and support notions of citizenship that differentiate between citizens who should be protected and those who should be monitored.
\end{abstract}

Keywords Biological determinism • Biogenetics • Epigenetics • Neurobiology $\bullet$ Stigmatization $\bullet$ Nature $\bullet$ Nurture 


\section{Biological Determinism: The Work of Cesare LOMBRoso}

Cesare Lombroso (1835-1909), the psychiatrist who was the father of criminal anthropology, marked indelibly the history and trajectory of biological explanations for criminal behaviour. Two distinctive features typify Lombroso's positivist approach: the first one is linked to a commitment towards collecting data through empirical observation. The collection of body measurements, such as weight, height and relative proportion of several body parts, was aimed at producing knowledge based upon alleged numerical objectivity (Rose \& Abi-Rached, 2013, p. 170). The second distinctive feature of Lombroso's approach is connected to the premise that propensity for crime is inscribed in individual biology (Walklate, 2007). According to the author's approach, this means that propensity for crime can be identified through "visible marks of criminality" that materialize in physical, moral, degenerative and unalterable features (Cole, 2001; Horn, 2003; Rose, 2000).

In the publications L'Uomo Delinquente (1876, “The Criminal Man”) and Le Crime, causes et remèdes (1899, "Crime, Its Causes and Remedies"), which are based on studies influenced by Darwin's natural selection theories, Lombroso defends that "criminals" are characterized by biological inferiority and possess "atavistic" physical and psychological traits that show physical and psychological "atavism" of a hereditary nature. Such traits are considered as being reminiscent of the earlier stages of human evolution (Dunnage, 2018; Newburn, 2007; Twine, 2002; Walklate, 2007). Based upon such principles, the author outlines the features of an "ideal-type" of "born criminal", that is, someone biologically predisposed for criminal activities. Among the physical traits listed by Lombroso we can find the "abnormal" shape or size of the skullcap and face, thick eyebrows, prominent molars, big, deformed ears, bodily dissymmetry and large size of arms, hands and feet. In terms of behaviour and personality traits, Lombroso argues that these individuals are characterized by reduced sensibility to pain, cruelty, recklessness, aversion to work, instability, vanity, penchant for superstition and sexual precociousness. This way, Lombroso sketches a general portrait for criminals anchored in implicit and explicit assumptions about biological traits that are conceived as being independent of specific historical, social or political context (Klein, 2013, p. 195; Smart, 1995). 
The scientific and political implications of this approach were extensive in their impact and reach. According to the postulates of criminal positivism, if an individual's criminal behaviour can be determined by innate individual traits, the goal of the justice system must be the incapacitation and treatment of these individuals until they are no longer a threat to society (Walklate, 2007). This type of logic framed the eugenic strategies that proliferated in the US and Europe towards the end of the nineteenth century and beginning of the twentieth century (Aungles, 1990; Duster, 2003; Rose, 2000), involving initiatives such as permanent segregation, marriage restrictions, restrictive immigration policies and compulsory sterilization (Newburn, 2007).

Eugenic strategies formed a movement with multiple modalities and a very questionable history, partly due to the association with the eugenic philosophies adopted by the Nazis in 1930 (Newburn, 2007). Following that kind of repercussion, biological theories about criminal behaviour received harsh criticism and became controversial, which pushed them to the outskirts of the scientific community and consigned them, for many years, to become synonym with scientific obscurantism (Machado, 2015).

\section{Biogenetic Explanations of Criminal Behaviour}

Notwithstanding the numerous controversies that have dogged the postulates of biological determinism, since the 1980s there has been a growing trend to reinvigorate and legitimize studies that put biology and genetics at the forefront (Baker, Tuvblad, \& Raine, 2010; Mednick, Moffitt, \& Stack, 1987; Walsh \& Beaver, 2009). Trying to move away from the pernicious implications of approaches based upon the biological determinism defended by Lombroso and some of his successors, the reinvigoration of biogenetic explanations for criminal behaviour is sustained by features that differ from the perspectives that precede them. A few guiding principles stand out in this regard. The first one refers to a focus on violent behaviour and criminal practices, considered by the scientific community as the most "likely" to be influenced by biological factors. Within this context, the potential usefulness of investigating epidemiological strategies in terms of public health was defended (Akers \& Lanier, 2009; Lanier, 2010), in particular those aiming to calculate the risk of being biologically predisposed for criminality (Raine, 2013).

Therefore, the locus where the interest resides moves from looking for the criminal or aggressive genes towards identifying, intervening, taking 
precautions and preventing risks, in order to identify vulnerabilities liable to increase an individual's propensity for violent conduct (Rose \& AbiRached, 2013). As shown by Nikolas Rose and Joelle Abi-Rached, this kind of approach is perfectly in line with our current socio-political juncture, where crimes are not just seen as infractions but also as public safety problems, generating economic burdens. In the author's words:

Within these control strategies of precaution, prevention and pre-emption, the question shifts from that of response to the offense after the act, to programmes of prediction and prevention that identify those at risk of the basis of a kind of algorithm that combines genetic and neurobiological factors with those relating to family life, parental behaviour, poverty, housing and other environmental factors. For these violent or impulsive behaviours at least, crime, is reframed as a problem of public health. (Rose \& Abi-Rached, 2013, p. 190) [added italics]

The reinvigoration of biogenetic explanations for criminal behaviour is closely linked to the emergence and consolidation of genetics and neuroscience. These new sciences, imbued with significant symbolic power, are able to lend scientific relevance to the studies aiming to turn human biology into a readable entity (Pavlich, 2009; Rose, 2000; Twine, 2002; Walby \& Carrier, 2010). There has been, however, an important shift: in the nineteenth century, the focus resided at the molar body, which was visible, tangible and easily revealed to the gaze of the experts. Nowadays, however, the focus on the body has been supplemented by the molecular level. A multitude of increasingly sophisticated biometric technologies and visualization devices nowadays renders the interior of the organic body readable while simultaneously allowing to decompose, anatomize, manipulate and amplify it at the molecular level (Rose, 2001, 2007). One example of a biometric technology that aims to render criminal bodies as readable is forensic DNA phenotyping that will be addressed in Chap. 7 of this book.

The proliferation of new technologies aimed at reading the body thus consolidates a new ontology of bodily datafication (French \& Smith, 2016; Hindmarsh \& Prainsack, 2010; Kloppenburg \& van der Ploeg, 2018; Smith, 2016). This specific ontology is based on the notion that the reading of the body may provide an objective and indisputable source of truth about a person's identity (Aas, 2006; Kloppenburg \& van der Ploeg, 2018). 
Finally, another guiding principle of this reinvigorated wave of studies that interlinks biology and criminality is its inscription into perspectives which conjugate genetic elements with social environments and the individual's psychological traits (Walsh \& Beaver, 2009) - a theme to be addressed in detail in the next section of this chapter.

\section{Nature (Versus) Nurture}

Epigenetics is one of the recent trends which most clearly illustrates the articulation between biogenetic and social aspects. In brief, epigenetics is a new post-genomic field of research, which has been growing and developing at an accelerated rate. It studies the molecular mechanisms regulating the roles of genes without altering the DNA sequence. The main principles underlying this field of research convey the idea that epigenetic mechanisms are: (1) sensible to environmental factors and lifestyles-in other words, instead of being determined exclusively endogenously, biological systems have enough flexibility to react to environmental changes (Loi, Del Savio, \& Stupka, 2013, p. 143); (2) established at an early development stage, with effects that can manifest themselves on a lifelong basis; (3) potentially transferable to subsequent generations (Hedlund, 2012; Loi et al., 2013); (4) possibly reversible through pharmacological and/or behavioural interventions (Tremblay \& Szyf, 2010).

Although most investigations in the field of epigenetics are based upon incipient scientific discoveries, performed on animals and under experimental conditions, there is a significant eagerness to extrapolate the preliminary results to human behaviour (Richardson, 2015). Both the scientific community and popular culture have shown a marked interest in the potential uses of this field of post-genomic research in terms of public health (Meloni \& Testa, 2014).

Nevertheless, attitudes and reactions regarding the potential held by epigenetics are subdivided. On the one hand, some researchers consider epigenetics as a new way of thinking that recognizes the importance of social aspects. On the other hand, others have remained sceptical on whether this new approach entails less biocentrism or if it is a cloaked way to reproduce "simple" biological explanations for complex social issues (Lloyd \& Müller, 2018, pp. 675-676). Within the scope of this second position, some authors have alerted to the fact that epigenetic approaches may come to constitute new types of biological determinism (Richardson, 
2015). As outlined by Stephanie Lloyd and Ruth Müller, "environmental epigenetics might also engender novel forms of biological essentialism, particularly if epigenetic modifications are framed as permanent bodily marks that determine the potentials of individuals and groups who have been exposed to potentially 'harmful' environments" (Lloyd \& Müller, 2018, p. 676).

The study of criminal behaviour is one of the fields where the contributions of epigenetics have been more readily "absorbed". Richard E. Tremblay is one of the most influential authors in this field, a psychology professor at the University College Dublin who was labelled as "the accidental epigeneticist" by Nature (Hall, 2013). After developing, over the course of several years, longitudinal studies with pre-school children evidencing aggressive behaviour and coming to the conclusion that disruptive behaviours are more significant in the earliest infancy stages, Richard Tremblay began working with Moshe Szyf, a geneticist and professor of pharmacology and therapeutics at McGill University. Together, the two academics created an approach that explores the development of chronic aggressive behaviours through epigenetics (Tremblay \& Szyf, 2010).

In brief, Tremblay and Szyf defend that epigenetic marks, modulated by the environment and by how children are nurtured by their mothers during the prenatal period and immediately following the birth, are fundamental to define the level of predisposition towards aggressive behaviour. The moment of conception and even that of preconception are, therefore, focal points of interest, where mothers are considered as the fundamental agents who will determine children's future behaviours. Among the risk factors specifically connected to mothers, the two authors listed the following: pregnancy at a young age, history of behavioural issues, reduced educational resources, consumption habits of tobacco, alcohol and other substances, mental health issues, problematic intimate relationships, poverty and coercive motherhood (Tremblay, 2010; Tremblay \& Szyf, 2010).

Tremblay and Szyf defend the creation and implementation of strategies for precocious and intergenerational prevention with women. The defence of this highly controversial point of view is based, according to the authors, on presupposing that women who possess a few, or all, of these risk factors will be more prone to have children who will subsequently develop aggressive behaviours. Thus, according to the authors, society 
must invest in intensive perinatal interventions to apply preventive and corrective measures to women of specific groups. According to Richard Tremblay:

The evidence suggests that preventing the development of serious disruptive behaviour problems should start at conception, at the latest, and needs to target females who have a history of social adjustment problems. In essence we need to turn on its head our thinking about prevention of disruptive behaviour: males are much more affected, but females should be our prime target to prevent a new generation of males and females with disruptive behaviour. (Tremblay, 2010) [added italics]

Construing the mothers' bodies as "epigenetic vectors" will lead to strategies liable to increase the already high levels of control applied to the female body (Richardson, 2015). Moreover, as evidenced by the quote above, the category "women" does not simply emerge monolithically from the epigenetic approach: this perspective is focused on women from disadvantaged social backgrounds, which intersecting with class, race, age and ethnicity, face specific patterns of oppression and discrimination (Andersen \& Collins, 2004; Burgess-Proctor, 2006; Weber, 2001). This shows the discriminatory and invasive potential of these approaches among more vulnerable social groups, as they expand, in terms of impact and reach, the type of social control applied to the reproductive female body (Richardson, 2015; Richardson et al., 2014).

However, this kind of reconfiguration of collective and individual responsibility is not restricted to recent epigenetic approaches (Meloni \& Testa, 2014; Pickersgill, Niewöhner, Müller, Martin, \& CunninghamBurley, 2013; Richardson, 2015). By analysing the trajectory of neuroscience when trying to explain criminal behaviours, Nikolas Rose and Joelle Abi-Rached (2013) show why there is a growing tendency to defend the connection between child deprivation, cerebral development and future behavioural problems, particularly if we follow the assumption that a child's brain is malleable, and therefore very influenced by the objective conditions of his life. Some authors have argued that children who suffered from neglect during their infancy are more prone to develop antisocial behaviours in later stages of their lives (Perry, 2002, 2009). As noted by Rose and Abi-Rached, over time and through different sources of legitimacy, the family is indicated as the epicentre for the development of criminal behaviour: 
We find the repeated arguments that one should minimize the host of social ills, including criminal and antisocial conduct, by governing the child through its family. [...] Social justice, it seems, lies not in tackling the causes of structural inequality, poverty, poor housing, unemployment, and the like, but in managing parents in the name of the formation of good citizens. (Rose \& Abi-Rached, 2013, p. 196)

This type of approach, which puts the family as the cornerstone to explain criminal behaviour, configures new models for biocitizenship. On the one hand, as they allow the body of certain individuals to be construed as a menace to public health and safety. On the other hand, by underlining the potentially hereditary of predisposition towards aggressive and criminal behaviour, these approaches also construe entire families as potential threats. Underlying to this line of action is the emergence of the concept of "anti citizen", in other words, individuals categorized as biologically predisposed to risks, and towards whom it is justifiable to apply a set of control and monitoring activities and policies, even if they do not present any evidence of deviant or criminal behaviour (Rose, 2000, p. 17).

\section{Concluding Remarks}

Despite being consigned to obscurity and considered as "bad science" for many years, the reinvigoration of biogenetic approaches to criminal behaviour is presently an unavoidable milestone in the current framework of the governance of crime. Such a tendency is symptomatic of the genetization, molecularization and biologization of our contemporary society.

Within the scope of current studies, which are increasingly focused on body datafication ontologies, we seem to be witnessing a blurring of the boundaries between nature and nurture. Notwithstanding, we can also see how the symbolic power of genetics and technology have the potential to configure new kinds of biological determinism that may expand and increase, both in their impact and reach, the marginalization of certain social groups. Such groups are outlined according to social categories of gender, race and class, which are then confronted with biogenetic approaches that differentiate between law-abiding citizens, who should be protected, and anti-citizens, immediately monitored and controlled since they are in their mother's womb. 


\section{REFERENCES}

Aas, K. F. (2006). "The body does not lie": Identity, risk and trust in technoculture. Crime, Media, Culture, 2(2), 143-158. https://doi.org/10.1177/ 1741659006065401

Akers, T. A., \& Lanier, M. M. (2009). "Epidemiological criminology": Coming full circle. American Journal of Public Health, 99(3), 397-402. https://doi. org/10.2105/AJPH.2008.139808

Andersen, M. L., \& Collins, P. H. (2004). Race, class, and gender. Belmont, CA: Wadsworth.

Aungles, A. (1990). The home and the prison. University of Wollongong. Retrieved from http://ro.uow.edu.au/theses/1730

Baker, L., Tuvblad, C., \& Raine, A. (2010). Genetics and crime. In The $S A G E$ handbook of criminological theory (Vol. 262, pp. 21-40). London: Sage Publications

Burgess-Proctor, A. (2006). Intersections of race, class, gender, and crime: Future directions for feminist criminology. Feminist Criminology, 1(1), 27-47. https://doi.org/10.1177/1557085105282899

Cole, S. (2001). Suspect identities: A history of fingerprinting and criminal identification. Harvard: Harvard University Press.

Dunnage, J. (2018). The work of Cesare Lombroso and its reception: Further contexts and perspectives. Crime, Histoire \& Sociétés/Crime, History \& Societies, $22(2), 5-8$.

Duster, T. (2003). Backdoor to engenics. New York: Routledge.

French, M., \& Smith, G. (2016). Surveillance and embodiment: Dispositifs of capture. Body \& Society, 22(2), 1-25. https://doi.org/10.1177/1357 $034 \times 16643169$

Hall, S. S. (2013). Behaviour and biology: The accidental epigeneticist. Nature, 505(January), 14-17. https://doi.org/10.1038/505014a

Hedlund, M. (2012). Epigenetic responsibility. Medicine Studies, 3(3), 171-183. https://doi.org/10.1007/s12376-011-0072-6

Hindmarsh, R., \& Prainsack, B. (Eds.). (2010). Genetic suspects: Global governance of forensic DNA profiling and databasing. Cambridge: Cambridge University Press.

Horn, D. G. (2003). The criminal body: Lombroso and the anatomy of deviance. New York: Routledge.

Klein, D. (2013). The etiology of female crime. In E. McLaughlin \& J. Muncie (Eds.), Criminological perspectives. A reader (pp. 195-226). London: Sage Publications.

Kloppenburg, S., \& van der Ploeg, I. (2018). Securing identities: Biometric technologies and the Enactment of human bodily differences. Science as Culture, 1-20. https://doi.org/10.1080/09505431.2018.1519534 
Lanier, M. (2010). Epidemiological criminology (EpiCrim): Definition and application. Journal of Theoretical and Philosophical Criminology, 2(1), 63-103.

Lloyd, S., \& Müller, R. (2018). Situating the biosocial: Empirical engagements with environmental epigenetics from the lab to the clinic. BioSocieties, 13(4), 675-680. https://doi.org/10.1057/s41292-017-0094-8

Loi, M., Del Savio, L., \& Stupka, E. (2013). Social epigenetics and equality of opportunity. Public Health Ethics, 6(2), 142-153. https://doi.org/10.1093/ phe/pht019

Machado, H. (2015). Genética e suspeição criminal: reconfigurações atuais de coprodução entre ciência, ordem social e controlo. In F. Cláudia \& H. Machado (Eds.), Ciência, identificação e tecnologias de governo. Rio Grande do Sul: Coleções Editoriais do CEGOV, 38-55. https://estudogeral.sib.uc.pt/bitstream/10316/41096/1/Gen\%c3\%a9tica\%20e\%20suspei\%c3\%a7\%c3\% a3o\%20criminal.pdf.

Mednick, S. A., Moffitt, T. E., \& Stack, S. A. (1987). The causes of crime: New biological approaches (S. A. Mednick, T. E. Moffitt, \& S. A. Stack, Eds.). Cambridge: Cambridge University Press. https://doi.org/10.2307/2071970 Meloni, M., \& Testa, G. (2014). Scrutinizing the epigenetics revolution. BioSocieties, 9(August), 1-26. https://doi.org/10.1057/biosoc.2014.22

Newburn, T. (2007). Criminology. Cullompton, Devon: Willan Publishing.

Pavlich, G. (2009). The subjects of criminal identification. Punishment \& Society, 11(2), 171-190. https://doi.org/10.1177/1462474508101491

Perry, B. D. (2002). Childhood experience and the expression of genetic potential: What childhood neglect tells us about nature and nurture. Brain and Mind, 3, 79-100.

Perry, B. D. (2009). Examining child maltreatment through a neurodevelopmental lens: Clinical applications of the neurosequential model of therapeutics. Journal of Loss and Trauma, 14(4), 240-255. https://doi.org/10.1080/ 15325020903004350

Pickersgill, M., Niewöhner, J., Müller, R., Martin, P., \& Cunningham-Burley, S. (2013). Mapping the new molecular landscape: Social dimensions of epigenetics. New Genetics and Society, 32(4), 429-447. https://doi.org/10.1080 /14636778.2013.861739

Raine, A. (2013). The anatomy of violence: The biological roots of crime. New York: Random House.

Richardson, S. (2015). Maternal bodies in the postgenomic order. In S. S. Richardson \& H. Stevens (Eds.), Postgenomics: Perspectives on biology after the genome (pp. 210-231). Durham and London: Duke University Press.

Richardson, S., Daniels, C. R., Gillman, M. W., Golden, J. L., Kukla, R., Kuzawa, C., \& Rich-Edwards, J. (2014). Society: Don't blame the mothers. Nature, 512, 131-132. https://doi.org/10.1038/512131a 
Rose, N. (2000). The biology of culpability: Pathological identity and crime control in a biological culture. Theoretical Criminology, 4(1), 5-34. https://doi. org/10.1177/1362480600004001001

Rose, N. (2001). The politics of life itself. Theory, Culture \& Society, 18(6), 1-30.

Rose, N. (2007). The politics of life itself: Biomedicine, power, and subjectivity in the twenty-first century. Princeton: Princeton University Press.

Rose, N., \& Abi-Rached, J. (2013). Neuro: The new brain sciences and the management of the mind. Princeton, NJ: Princeton University Press.

Smart, C. (1995). Law, crime and sexuality: Essays in feminism. London: Sage Publications.

Smith, G. (2016). Surveillance, data and embodiment: On the work of being watched. Body \& Society, 22(2), 108-139. https://doi.org/10.1177/1357 $034 \mathrm{X} 15623622$

Tremblay, R. E. (2010). Developmental origins of disruptive behaviour problems: The "original sin" hypothesis, epigenetics and their consequences for prevention. Journal of Child Psychology and Psychiatry and Allied Disciplines, 51(4), 341-367. https://doi.org/10.1111/j.1469-7610.2010.02211.x

Tremblay, R. E., \& Szyf, M. (2010). Developmental origins of chronic physical aggression and epigenetics. Epigenomics, 2(4), 495-499. https://doi. org/10.2217/epi.10.40

Twine, R. (2002). Physiognomy, phrenology and the temporality of the body. Body \& Society, 8(1), 67-88. https://doi.org/10.1177/1357034X02008 001004

Walby, K., \& Carrier, N. (2010). The rise of biocriminology: Capturing observable bodily economies of 'criminal man'. Criminology \& Criminal Justice, 10(3), 261-285. https://doi.org/10.1177/1748895810370314

Walklate, S. (2007). Understanding criminology: Current theoretical debates (3rd ed.). New York: Open University Press.

Walsh, A., \& Beaver, K. M. (2009). Biosocial criminology. In M. D. Krohn, A. J. Lizotte, \& G. P. Hall (Eds.), Handbook on crime and deviance (pp. 79-101). Dordrecht, Heidelberg, London, New York: Springer. Retrieved from https:// link.springer.com/content/pdf/10.1007\%2F978-1-4419-0245-0_5.pdf

Weber, L. (2001). Understanding race, class, gender, and sexuality: A conceptual framework. Boston: McGraw-Hill. 
Open Access This chapter is licensed under the terms of the Creative Commons Attribution 4.0 International License (http://creativecommons.org/licenses/ by $/ 4.0 /$ ), which permits use, sharing, adaptation, distribution and reproduction in any medium or format, as long as you give appropriate credit to the original author(s) and the source, provide a link to the Creative Commons licence and indicate if changes were made.

The images or other third party material in this chapter are included in the chapter's Creative Commons licence, unless indicated otherwise in a credit line to the material. If material is not included in the chapter's Creative Commons licence and your intended use is not permitted by statutory regulation or exceeds the permitted use, you will need to obtain permission directly from the copyright holder.

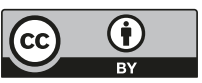

